\title{
SOIL FERTILITY AND LITTERFALL ASSESSMENT IN A PERI-URBAN FOREST OF SÃO PAULO, SP: UNDERSTANDING FOR URBAN GREEN AREAS MANEGEMENT
}

\author{
M.L.FERREIRA ${ }^{1}$, N.G.V.ANDRADE ${ }^{2}$, M.C.L.D.COSTA ${ }^{3}$, D.M.ARAUJO ${ }^{4}$, P.L.CÔRTES ${ }^{5}$, C.C.QUARESMA ${ }^{6}$, D.M.CONTI', \\ P.B.CAMARGO ${ }^{8}$ \\ Universidade Nove de Julho ${ }^{1,2,3,4,6,7}$, Universidade de São Paulo ${ }^{5,8}$ \\ mauecologia@yahoo.com.br ${ }^{1}$
}

Artigo submetido em 07/02/2019 e aceito em 27/11/2019

DOI: $10.15628 /$ holos.2019.8290

\section{ABSTRACT}

The Atlantic Forest is an important biome formed by different phytophysionomy and is considered a hot spot of biodiversity. Some parts of the biome has received more attention in recent studies but few articles has stood out in the physiognomy of nebular forest, especially in peri-urban forests. The objective of this study was to evaluate soil fertility and litterfall production and decomposition in a peri-urban forest of São Paulo city, Brazil. The studied area is located at the Curucutu nucleus, at the State Park of Serra do Mar, southern of São Paulo city. The phytofisignomy is characterized by dense broadleaf vegetation in a nebular forest. Five different points were selected in 1 ha plot to collect soil samples at 0-10, 10-20, 20-30 cm depths to analyze physicochemical properties. For analysing litterfall production 20 litter traps were randomly distributed in the plot. After collected, the material was dried and weighted. For decomposition, sixty
\end{abstract}

litter bags were randomly placed on the soil and 12 of them were monthly collected to assess the biomass loss. The results indicated low nutrient availability and high values of aluminum in the soil due to extremely acidic conditions. The soil C:N, C:P and P:N ratios showed an inefficiency in nutrient cycling probably due to the slow decomposition rate, which probably contributed to low availability of nutrients. Litterfall production reached the amount of 6.4 $\mathrm{Mg}$ ha-1 year-1 with the highest production during the spring and summer. The litter bags methodology confirmed the lower decomposition rates and the time to decompose $50 \%$ and $95 \%$ of the material was higher than the expected for fragments of the Atlantic forests. The low values of macro and micronutrients verified, associated with the acidity and the presence of toxic element, affect the fertility of the soil at the Curucutu, resulting in nutritional deficiencies to the existing vegetation.

\section{Keywords: Tropical Soil; Cation Exchangeable Capacity; Nutrient Cycling; Phenology. \\ FERTILIDADE DO SOLO E AVALIAÇÃO DE QUEDA EM UMA FLORESTA PERI-URBANA DE SÃO PAULO, SP: COMPREENSÃO DA GESTÃO DE ÁREAS VERDES URBANAS \\ RESUMO}

A Mata Atlântica é um bioma importante formado por diferentes fitofisionomias, sendo considerado um hot spot da biodiversidade. Algumas partes do bioma têm recebido mais atenção em estudos recentes, porém poucos artigos se destacaram no estudo da fisionomia da floresta nebular, especialmente em florestas periurbanas. O objetivo deste estudo foi avaliar a fertilidade do solo, a produção e a decomposição de serapilheira em uma floresta peri-urbana da cidade de São Paulo. A área de estudo está localizada no núcleo Curucutu do Parque Estadual da Serra do Mar, na região sul da cidade de São Paulo, Brasil. A fitofisionomia é caracterizada por uma vegetação densa de folhas largas em uma floresta nebular. Cinco diferentes pontos foram selecionados em uma parcela de 1 ha para recolher amostras de solo a 0-10, 10-20, 20-30 cm de profundidade para analisar as propriedades físico-químicas e fertilidade. Para a análise da produção de serapilheira 20 coletores foram distribuídos aleatoriamente na parcela. Depois de recolhido, o material foi seco e pesado em balança digital. Para a decomposição, sessenta sacolas de decomposição foram dispostas aleatoriamente no solo da floresta, sendo 12 delas coletadas mensalmente para avaliar a perda de biomassa. Os resultados indicaram baixa disponibilidade de nutrientes e valores elevados de alumínio no solo devido à condição de acidez elevada. As razões C:N, C:P e $P: N$ do solo indicaram ineficiência na ciclagem de nutrientes, provavelmente, devido à taxa de decomposição lenta, o que provavelmente contribuiu para a baixa disponibilidade de nutrientes no sistema edáfico. $A$ produção de serapilheira alcançou a quantidade de $6,4 \mathrm{Mg}$ ha-1 ano-1, com a maior produção durante a primavera e o verão. A perda de biomassa de serapilheira nas sacolas dispostas aleatoriamente confirmou baixa taxa de decomposição, sendo que o tempo para decompor $50 \%$ e 95\% do material foi mais elevado do que o comparado com outros fragmentos de Florestas Atlântica. Os baixos valores de macro e micronutrientes verificados, associados à elevada acidez e à presença de elemento tóxico, afetam a fertilidade dos solos do Núcleo Curucutu, resultando em deficiências nutricionais para a vegetação existente.

Palavras-chave: Floresta Tropical; CTC; Ciclagem De Nutrientes; Fenologia. 


\section{INTRODUCTION}

In tropical forests, soil organic matter (SOM) is responsible for most of the stored nutrients in the edaphic compartment, where carbon represents the highest proportion (Batjes, 2014). The amount of SOM is dependent on both, the availability of accumulated organic sediments and the rate of litterfall decomposition performed by microorganisms (Ostertag et al., 2008). When combined with other elements such as nitrogen and phosphorus, carbon may serve as an indicator of decomposition rate and consequently indicate the fertility of the compartment. Besides $\mathrm{C}$, the low availability of $P$ in the soil limits the productivity of tropical ecosystems (Aragão et al., 2009), being its deficiency mainly caused by a strong adsorption of $\mathrm{H}_{2} \mathrm{PO}_{4}$ to aluminum (Al) and iron (Fe) oxides, which turns large proportions of total $\mathrm{P}$ in forms unavailable for plants.

In general, tropical forests have efficient mechanisms for nutrient cycling (Vitousek, 1984), and one way for analyzing this process is through the compartmentalization of accumulated biomass in different strata and the quantification of nutrient rates that move between the compartments through litterfall decomposition (Hoobie and Vitousek, 2000; Van Groeningen et al., 2015). Thus, decomposition plays a key role in the transfer of energy among the web chain, contributing for the maintenance of the ecosystems (Silva et al., 2007; Aryal et al., 2015) and soil fertility. Scheer (2008) describes the dependency of late successional vegetation to the litterfall produced by pioneer species, which contributes to the refund of organic matter in surface soil horizons and to the provision of nutrients (Van Groeningen et al., 2015).

The Atlantic Forest is an important biome formed by different phytophysionomy and is considered a hot spot of biodiversity (Myers, 2000). Some parts of the biome has received more attention in recent studies of plant diversity, tree biomass, litterfall and soil characteristics (Vieira et al., 2008; Alves et al., 2010; Joly et al., 2012; Susian et al., 2015), but few articles has stood out in the physiognomy of nebular forest, especially in urban and peri-urban forests, where lower air temperature, oligotrophic soil and strong winds predominate (Martins, 2012; Eller et al., 2013).

Many cities within this biome have been heavily influenced by economic activities, and as a result they have promoted an intense process of immigration with serious social and environmental consequences such as the uncontrolled demography increasing, the emission of high levels of air contaminants and the loss of biodiversity (Grimm et al., 2008; Mcgranahan, 2008; Tabarelli et al., 2010; Lira et al., 2012; Jesus et al., 2014; Specht et al., 2015). This is the case of São Paulo city, which still presents in its extreme south region some fragments of green areas in a rural zone which has gradually been urbanized. Thus, it is expected that forests bordering large cities and metropolitan regions might suffer changes in ecological process such as litterfall dynamics and nutrient cycling.

Thus, we hypothesized that a 40 years old peri-urban forest of São Paulo city would show poor soil fertility due to a slow process of nutrient cycling characterized by low litterfall decomposition rate and low litterfall production. The area hosts a high diversity of species and is located near the south region of São Paulo (about $50 \mathrm{~km}$ from the city center), which has a population of about 21 million people (UN, 2015) and an intense economic activity. Despite the 
nucleous belong to the State Park of Serra do Mar, the region might be threatened by urban anthropogenic interference such as air pollution or cattle activities. So, this study aimed to evaluate the soil fertility characteristics, litterfall production and decomposition in this fragment of the Atlantic Forest located in a transition of São Paulo metropolitan region and the Serra do Mar State Park, one of the largest continuous of forest in the Atlantic domain (Ribeiro et al., 2009).

\section{MATERIALS AND METHODS}

\subsection{Study area}

The Curucutu nucleous is an environmental reserve belonging to the Serra do Mar State Park, located at the southern end of the São Paulo city (Figure 1), about $50 \mathrm{~km}$ from the city center (23058'17.49"S 4645'26.00"W). This nucleus occupies an area of 25,000 ha just about 100-1000 m above sea level. The topography of the area is undulating with slope above 30 . Local annual rainfall is high and exceeds $2000 \mathrm{~mm}$. Despite extending from the lowlands to the montana region of the dense rain forest of the Atlantic domain, this study occurred in the middle part of the elevation gradient, at $790 \mathrm{~m}$ of altitude, in an area characterized by nebular forest. The vegetation has smallsized trees with twisted branches, with a predominance of pioneer species (Neto, 2007). This secondary forest is about 40 years old and was regenerated after intensive logging in the region (Institute Ekos, 2006).

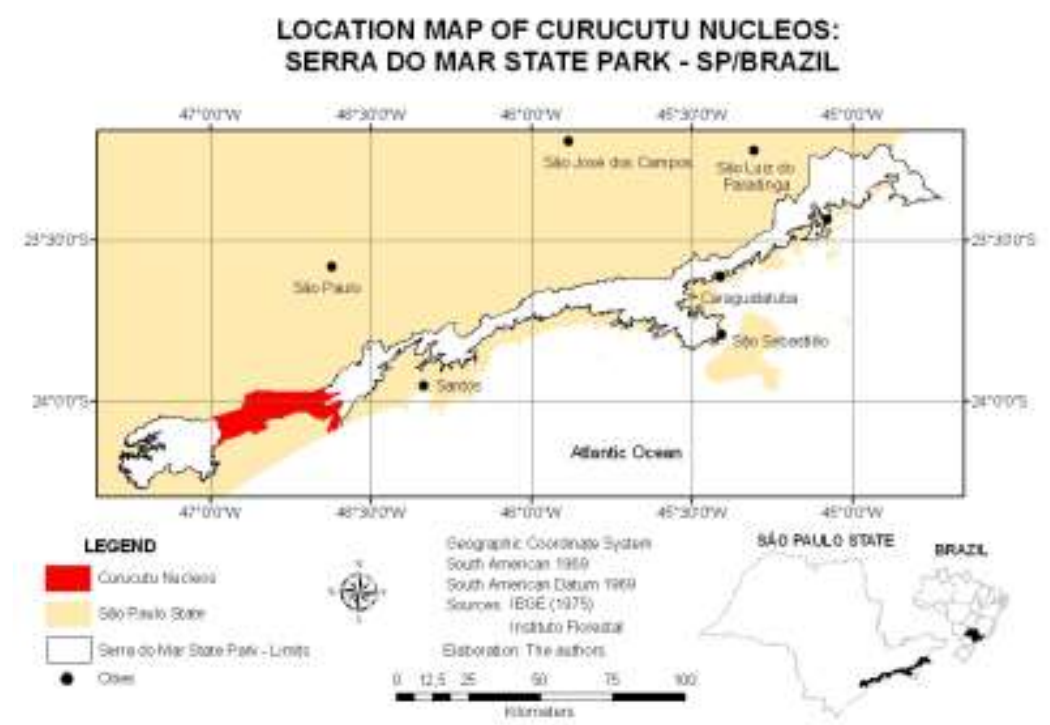

Figure 1: Location map of Curucutu Nucleous: Serra do Mar State Park, SP, Brazil.

\subsection{Soil analysis}

The soil samplings were taken in August 2013 in a 1 ha plot at 5 points randomly chosen. On the chosen drilling, an organic mantle surface that covered the soil was removed and holes with about $40 \mathrm{~cm}$ diameter and $40 \mathrm{~cm}$ deep were opened using spade holes. In the walls of each cavity, 
soil samples were collected at 0-10 cm, 10-20 cm and 20-30 cm depths, as described by Costa et al., (2009), considering zero the end of the 0 horizon. Additionally, three more soil samples were collected for determination of texture and moisture. All soil samples were submitted to physicochemical analysis, such as fertility, nutrient availability ( $N, C, K, P, M g, A l, C a)$, soil organic matter (SOM), pH, cation-exchangeble capacity. The methodological approach adopted followed the protocol described by the Agronomic Institute of Campinas (Raij et al., 2001) for analysis of tropical soils.

The results were compared with the values proposed by Raij et al., (1985). Some of the chemical indices used for fertility assessment were percentage of base (V\%) and aluminum saturation ( $\mathrm{m} \%$ ), as established by the Brazilian Agricultural Research Company (Embrapa, 2006). According to our analysis, soil samples correspond to a Oxisol, according to Soil Survey Staff (1999), with the presence of quartz, kaolinite clay type 1:1, characterized by presenting laminae (one silica and one alumina) rich in iron and aluminum oxides, with low to medium levels of organic matter (Raij et al., 2001).

The soil was extremely shallow, in which hard sediment was found at $40 \mathrm{~cm}$ depth, probably the bedrock in changing state. The soil texture was classified as loam with variations between sandy loam, silt loam and sandy clay loam, because it has unequal proportions of sand, clay and silt. The observed particle size standard justifies the mean value of $31.33 \%$ of natural moisture, because in soils with a predominance of fine grains there is greater retention of water particles in relation to sandy soils.

\subsection{Litterfall production and decomposition}

To assess the litterfall production 20 collectors were randomly distributed about 0.5 meters from the soil in an area of 1 ha (Schumacher et al., 2011). The material was monthly collected during one year, from April of 2012 to March of 2013, dried in an oven at 65 ㅇ for 7 days or until reach constant weight. After drying, the material was weighted in an analytical balance accurate to 0.01 g. The amount of litterfall produced was estimated with the following model, proposed by Menezes et al., (2010) and used by Ferreira et al., (2014a):

$$
\mathrm{L}=\frac{\sum \mathrm{M} * 10,000}{\mathrm{ca}}
$$

where: $\mathrm{L}=$ litterfall production $\left(\mathrm{kg} \mathrm{ha}^{-1} \mathrm{year}^{-1}\right) ; \mathrm{M}=$ monthly production of litter $\left(\mathrm{kg} \mathrm{ha}^{-1}\right)$ and ca was the collector area $\left(\mathrm{m}^{2}\right)$.

The evaluation of biomass loss by decomposition was performed using litter bags. These nylon mesh bags with $25 \times 25 \mathrm{~cm}$ dimensions received $10 \mathrm{~g}$ of fresh material collected from the litter traps (leaves, stems, reproductive parts and miscellaneous). Sixty (60) litter bags were randomly scattered on the area and twelve bags were monthly collected after 30,60, 90, 120 and 150 days of exposure. The collected bags were taken to the laboratory to be washed in order to remove debris that settle on the bags and oven dried at 65 ㅇ for 7 days. The remaining material was weighed. The decomposition constant was obtained according to Ferreira et al., (2014a). The remaining biomass 
was expressed as (final weight / initial weight) $\times 100$. The decomposition constant $k$ was calculated according to the model proposed by (Shanks e Olson, 1961): $k=\ln (X / X 0) / t$, where: $X=$ dry weight of the remaining material after $\mathrm{t}$ days; $\mathrm{XO}=\mathrm{dry}$ weight at time zero and $\mathrm{t}=$ exposure time. The time to decompose $50 \%\left(t_{0,5}\right)$ and $95 \%\left(t_{0,05}\right)$ of the material was calculated according to Menezes et al. (2010), following the equation: $t_{0.5}=\ln (2) / K$, where: $k=$ is the constant of decomposition and $t_{0,05}=$ $3 / k$.

\subsection{Statistical analysis}

To compare the nutrients concentrations along the soil layers we firstly checked out the normal distributions of data by the Shapiro-Wilks test. After that we decided to use a nonparametric analyses of Kruskal-Wallis using PAST package for the comparison (Hammer et al., 2001). We adopted a marginal alfa of $10 \%$ once we had few samples per layer and the power of the test might be influenced by this factor. To analyze de difference between litterfall decomposition throughout the study, the data of biomass loss was firstly log transformed and after a Kruskal-Wallis was applied to detect significate differences between the time of exposure.

\section{RESULTS AND DISCUSSION}

\subsection{Soil nutrients and fertility}

The results of this study showed that upper layers of the soil $(0-10 \mathrm{~cm})$ presented larger amounts of organic matter, $\mathrm{C}$ and $\mathrm{N}$ showing that as the depth increased the concentrations of these variables decreased, so interfering in the amount of available SOM (Table 1). Phosphorus and potassium did not show any detectable variation along the layers. The macronutrients results indicate that the amount of organic matter might interferes in the soil biochemical characteristics once it represents more than $80 \%$ of the total cation-exchangleble capacity (Ronquim, 2010), playing an important role in the soil dynamics.

Table 1: Concentration of the main macronutrients and organic material at different soil depths in the Curucutu Nucleous. In the parenthesis the coefficient of variation (CV).

\begin{tabular}{llll}
\hline Nutrient & $0-10 \mathrm{~cm}$ & $10-20 \mathrm{~cm}$ & $20-30 \mathrm{~cm}$ \\
\hline $\mathrm{SOM}\left(\mathrm{g} \mathrm{dm}^{-3}\right)$ & $11(47 \%) \mathrm{a}$ & $6.6(39 \%) \mathrm{ab}$ & $5.0(60 \%) \mathrm{b}$ \\
$\mathrm{C}\left(\mathrm{g} \mathrm{dm}^{-3}\right)$ & $6.2(45 \%) \mathrm{a}$ & $3.8(34 \%) \mathrm{ab}$ & $2.8(60 \%) \mathrm{b}$ \\
$\mathrm{N}\left(\mathrm{mg} \mathrm{kg}^{-1}\right)$ & $644(32 \%) \mathrm{a}$ & $518(24 \%) \mathrm{ab}$ & $420(26 \%) \mathrm{b}$ \\
$\mathrm{P}\left(\mathrm{mmol}_{\mathrm{c}} \mathrm{dm}^{-3}\right)$ & $0.05(0 \%) \mathrm{a}$ & $0.05(0 \%) \mathrm{a}$ & $0.05(0 \%) \mathrm{a}$ \\
$\mathrm{K}\left(\mathrm{mmol}_{\mathrm{c}} \mathrm{dm}^{-3}\right)$ & $0.1(0 \%) \mathrm{a}$ & $0.1(0 \%) \mathrm{a}$ & $0.1(0 \%) \mathrm{a}$ \\
\hline
\end{tabular}




\begin{tabular}{cccc}
\hline Ca $\left(\mathrm{mmolc}^{-3}\right)$ & $3.0(33 \%) \mathrm{a}$ & $2.6(19 \%) \mathrm{a}$ & $2.4(20 \%) \mathrm{a}$ \\
$\mathrm{Mg}\left(\mathrm{mmolc} \mathrm{dm}^{-3}\right)$ & $1.4(35 \%) \mathrm{a}$ & $1.0(0 \%) \mathrm{a}$ & $1.2(33 \%) \mathrm{a}$ \\
\hline
\end{tabular}

Lowercase letters compares the variables in the groups of soil.

The amount of phosphorus observed in the samples are considered very low (Table 1 ) when compared to the limits described by Raij et al., (1985). Martins et al., (2005) found similar values for phosphorus in different types of forest, including settlement of Pinus sp., Eucalyptus sp. and native forest in Lavras (MG). The levels of $\mathrm{Ca}$ and $\mathrm{Mg}$ reported in this work are also considered low and $\mathrm{K}$ is considerable very low (Raij et al., 1985), which may negatively interfere in the maintenance and stabilization of the tree community. According to Maria et al., (1993), acidic soils have low concentrations of $\mathrm{Ca}$ and $\mathrm{Mg}$ and the process of lixiviation is the main responsible for the removal of these elements from the edaphic compartment by replacing the hydrogen to aluminum which further enhances the acidity, as shown in Table 2.

Table 2: Parameter representation of acidity and soil fertility. In the parenthesis the coefficient of variation (CV).

\begin{tabular}{|c|c|c|c|}
\hline Parameters & $0-10 \mathrm{~cm}$ & $10-20 \mathrm{~cm}$ & $20-30 \mathrm{~cm}$ \\
\hline $\mathrm{pH}\left(\mathrm{mmolc} \mathrm{dm}^{-3}\right)$ & $4.00(0 \%) a$ & $4.02(1 \%) a$ & $4.10(2 \%) a$ \\
\hline $\mathrm{Al}\left(\mathrm{mmolc} \mathrm{dm}^{-3}\right)$ & $7.6(15 \%) a$ & $6.8(21 \%) a$ & $6.4(17 \%) a$ \\
\hline $\mathrm{H}+\mathrm{Al}\left(\mathrm{mmolc} \mathrm{dm}^{-3}\right)$ & $42.6(16 \%) a$ & $38.8(27 \%) a$ & $42.6(38 \%) a$ \\
\hline $\mathrm{SB}\left(\mathrm{mmolc} \mathrm{dm}^{-3}\right)$ & $4.4(34 \%) a$ & $3.6(13 \%) a$ & $3.6(22 \%) a$ \\
\hline CTC $\left(\right.$ mmolc $\left.\mathrm{dm}^{-3}\right)$ & $47.0(18 \%) a$ & $42.4(24 \%) a$ & $46.2(35 \%) \mathrm{a}$ \\
\hline $\mathrm{m}(\%)$ & $61.4(8 \%) a$ & $61.2(7 \%) a$ & $68.4(8 \%) a$ \\
\hline V (\%) & 9.4(19\%)a & $9.2(28 \%) a$ & $8.6(33 \%) a$ \\
\hline
\end{tabular}

Where: $\mathrm{SB}=$ sum of bases, $\mathrm{CTC}=$ cation exchange capacity, $\mathrm{V} \%=$ base saturation, $\mathrm{m} \%=$ base saturation in aluminum. Lowercase letters compares the variables in the groups of soil.

The $\mathrm{pH}$ did not change significantly over the soil layers, remaining between 4.0 and 4.2 , which classifies this soil as extremely acid (Mcbratney et al., 2003; Sanches et al., 2003). Aluminium showed high values for tropical soil, which might contribute for intense potential acidity (H+Al) at all depths. Aluminum is absorbed by negatively charged colloid in $\mathrm{pH}$ lower than 5.6, neutralizing other available nutrients in the form of cations (Tian et al., 2013).

High levels of exchangeable Al are phytotoxic and cause adverse effects on plant nutrition, preventing other cations, such as $\mathrm{Ca}^{2+}, \mathrm{Mg}^{2+}$ and $\mathrm{K}^{+}$, to interact with the soil-plant system, which results in changes in patterns of absorption of other nutrients by the plant community and the consequent reduction in the root system grown (Salvador et al. 2000). 
Acidic soils with low availability of $\mathrm{Ca}, \mathrm{Mg}, \mathrm{K}$ and $\mathrm{P}$ and high levels of exchangeable aluminum can be found in Brazilian soils (Cardoso and Kuyper, 2006). Thus, the high levels of aluminum and potential acidity found in this study explain the low sum of bases (SB) (3.6 to $4.4 \mathrm{mmolc} . \mathrm{dm}^{-3}$ ) and bases saturation (V\%) (8.6 to $9.4 \%$ ) over the $0-30 \mathrm{~cm}$ depth profile. Similar results has been found by Rodrigues et al. (2016) in soil of the Atlantic forest, Parana, southeastern Brazil. Most plants exhibit high productivity when values of soil V\% vary between $50-80 \%$ and pH of 6.0 to 6.5 (Ronquim, 2010). Mean values for aluminum saturation (m\%) were greater than $60 \%$ in this work (Table 2 ).

The observed CEC in the present study is also the consequence of high levels of $\mathrm{H}^{+} \mathrm{Al}^{+3}$, since the low values of SB contributes just a little to the cation exchange capacity (Table 2). The presence of toxic cations as $\mathrm{Al}^{3+}$ burdening the process of CEC leads to the formation of poor soils, as this prevents essential cations $\left(\mathrm{K}^{+}, \mathrm{Mg}^{2+}\right.$ and $\left.\mathrm{Ca}^{2+}\right)$ to interact in the soil-plant system (Liang et al., 2006; Thomas et al., 2007).

Martins et al., (2015) evaluated the nutrient availability and soil fertility along an altitudinal gradient (0 to 1000 meters a.s.I.) in the Serra do Mar State Park, in the Atlantic Forest and found similar results to this study. The values found for the sum of bases are quite low compared to the values of $\mathrm{Al}$, contributing little to the CEC. This fact confirms the acidity of the soil with high values of $\mathrm{m} \%$, reinforcing the low soil fertility. Martins et al., (2015), which characterize a similar spatial variability in this part of the Atlantic domain. However, it should be noted that in these studies the authors worked in different depths, which was not possible in the present study due to the shallow soil (Bellato and Mendes, 2002). Also in comparison with the work of Martins et al., (2015), although nutrients and SB are lower than the values found by the authors, the value of saturation (V\%) was relatively higher, which may indicate that even with lack of nutritional resources, the cations $\mathrm{K}^{+}, \mathrm{Mg}^{+}$ + and $\mathrm{Ca}^{+}$might contribute positively in the soil-plant system.

\section{Ratios C:N, C:P and N:P}

The data presented in Table 3 show a decrease of nutrients along the soil depth. Several studies have shown the relationship of $\mathrm{C}$ and $\mathrm{N}$ abundance in litterfall decomposition and soil fertility, as well as their implications for restoration of degraded areas (Li et al, 2009; Vasconcellos et al., 2013; Martins et al., 2015). Prescott (2010) pointed out that the poverty of soil nutrients in a tropical region might be due to the slow decomposition process, impacting a reduction in the levels of available $P$ and $N$ (Table 3 ).

Table 3: Ratios C:N, C:P and N:P throughout the soil depth of the Curucutu Nucleous.

\begin{tabular}{llll}
\hline & $0-10 \mathrm{~cm}$ & $10-20 \mathrm{~cm}$ & $20-30 \mathrm{~cm}$ \\
\hline $\mathrm{C}: \mathrm{N}$ & 0.0096 & 0.0073 & 0.0067 \\
$\mathrm{C}: P$ & 3.10 & 1.90 & 1.40 \\
$\mathrm{~N}: \mathrm{P}$ & 322.0 & 259.0 & 210.0 \\
\hline
\end{tabular}


In an urban forest of São Paulo city, Ferreira et al., (2014b) observed amounts of C, N and P much higher than the values of the present study. This result may be related to other factors that influence litterfall decomposition, such as temperature and precipitation of the study area, since the precipitation rate is almost double in the Curucutu nucleus compared to the forest of this study. The low values of $\mathrm{C}: \mathrm{N}$ ratio indicates that a strong mineralization process of SOM may be occurring, as nitrogen availability in the system is relatively high. Pereira et al., (2008) worked in a fragment of the Atlantic Forest (Island Marambaia/RJ) and showed that in rainy months litterfall production was higher compared to the driest months. Araujo et al., (2011) found higher C:N ratio in forest soils than in pasture environment in the Amazon rainforest and explained that the forming material of litterfall and its accumulation in forest environments assist the decomposition process, beyond temperature and humidity that varies between both types of environment. In a study conducted in an Alfisol soil located at the Pernambuco Ecological Station, Silva (2011) found that the introduction of Gliricidea litter on pasture environment increased nutrient cycling, reducing the relations $\mathrm{C}: \mathrm{P}$ and $\mathrm{C}: \mathrm{N}$, providing greater decomposition of organic material and the consequent availability of $\mathrm{N}$ and $P$ to the soil, which explains the importance of the relationships between nutrient for the forest ecosystem dynamics and processes.

\section{Litterfall production and decomposition}

The community of the studied area produced a total of $6.47 \mathrm{Mg} \mathrm{ha}^{-1}$ year-1, with more deciduous material in September, November and January (1175, 778 and $806 \mathrm{~kg} \mathrm{ha}^{-1}$, respectively) and lower production in June and July (276 and $264 \mathrm{~kg} \mathrm{ha}^{-1}$, respectively). During the period with less pluviometric precipitation the amount of litter produced followed the rainfall curve, however, the same trend was not observed during the rainiest season (Figure $2 \mathrm{~A}$ ).

Although the amounts of rain and litterfall were higher during the spring and summer, the fall of the deciduous material seems to not have been controlled by the pluviometric precipitation, but, synchronized with the environment. This synchronization has been reported for plant phenology in tropical forests (Wu et al., 2016). Rowland et al., (2014) developed a study on the dynamics of tree growth in the Amazon and highlighted that the community seemed to be more synchronized than controlled by the environment.

The litterfall curve found in this work was similar to the some other authors who studied in areas of primary and secondary Atlantic forests, including an urban forest of São Paulo (Pereira et al., 2008; Menezes et al., 2010; Ferreira et al., 2014a; Ferreira and Uchiyama, 2015). The few works involving litterfall production in urban and peri-urban areas of the brazilian cities, especially those located in the Atlantic Forest biome, limits a greater understanding of the possible impacts that the metropolitan region of São Paulo might have in the dynamics of leaf litter. However, it is possible to infer that atmospheric pollution coming from São Paulo are reaching Curucutu nucleous, thus interfering in phenological processes (Kraepiel et al., 2015).

Ferreira and Uchiyama (2015) studied the litter in a secondary forest near the metropolitan region of São Paulo and found a similar trend to the present study, but with a strong influence of the rainfall and relative humidity on litterfall production. The authors suggested a possible hormonal 
response as a key factor for the leaves fall early in the season with the highest rainfall rates, probably triggered by decreased soil water availability (Zalamea and González, 2008; Menezes et al., 2010).
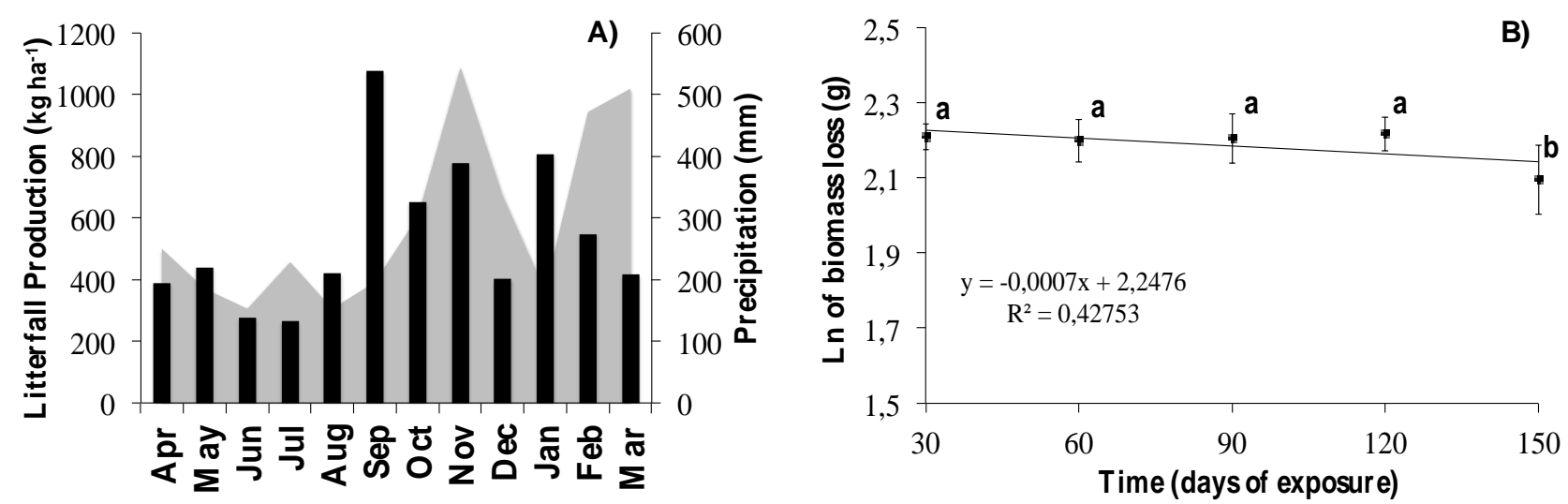

Figure 2: Litterfall production and decomposition. In (A) Monthly average of litterfall production $\left(\mathrm{kg} \mathrm{ha}^{-1}\right)$ and accumulated pluviometric precipitation over the sutudied year $(\mathrm{mm})$. In (B) the graph shows the loss of biomass over 150 days at intervals of 30 days. Biomass values transformed in $\log _{10}$. Lowercase letters compares the variables in the groups of soil considering $\alpha<0,5$ by Tukey test.

The log transformation data of biomass loss in the litterfall followed a linear model $y=0.0007 x+2,2476$ with regression coefficient of approximately 0.42 (Figure $2 B$ ). This is an atypical curve for tropical forests when compared to others similar areas (Pereira et al., 2008; Ferreira et al., 2014a). The Figure 2B shows that just up to 120 days of exposure the remaining material was significant lower, which could be related to a subtle increasing in the air temperature.

The decay constant $(k)$, the decomposition time of $50 \%\left(t_{0.5}\right)$ and $95 \%\left(t_{0.05}\right)$ of the material were respectively $0.014,508.5$ days and 6 years. At the end of the work just $14.76 \%$ of all litterfall was decomposed.

This value of decomposition constant was lower than the values found in other studies in the Atlantic Forest. Arato et al., (2003) found a decay constant of 1.17 in an agroforestry system deployed in degraded area in Viçosa - MG. Ferreira and Uchiyama (2015) found $k$ value of 3.1 for a secondary forest in Ibiúna, SP, and for $50 \%$ and $95 \%$ of the litterfall decomposition the authors found 2.58 and 11.28 months, respectively. Ferreira et al. (2014a) found $k=0.0027$ for an urban forest in São Paulo and Pereira et al., (2008) found $k=0.0023$ in a fragment of the Atlantic forest.

One possible explanation for this difference could be some environmental factors, such as air temperature and precipitation which could influence the microorganism's activity (BATISTA et al., 2017). Concomitantly, it is prudent to consider the influence of São Paulo's atmospheric pollutants once Ferreira et al., (2017) showed the study area was probably affected by air contaminants with critical influence in litterfall decomposition. About soil properties, Cianciaruso et 
al., (2006) reported that chemical and physical factors can be also critical to litterfall decomposition, which reinforces that part of these results could be explained by the extremely acidic soil conditions, since the values of soil pH might have negatively influenced the activity of microbial decomposers.

Thus, it is reasonable to assume that the lack of nutrients and high exchangeable aluminum values as a result of this sharp acidity indicate low efficiency in the nutrient cycling that can be attributed to the slow process of litter fall decomposition. As cited above, it should also be considered that air pollution may have reached the study area and altered the composition of the microbiota and/or the edaphic arthropodofauna (Ferreira et al., 2018). Ferreira et al. (2017) showed statistical differences in decomposition process of the litterfall exposed nearest to the urban center when compared to the metrial exposed farther from the city.

It should be noted that the compared lower value of $k$ may also be related to the composition of the material placed in the litter bags, since the bags were composed of mixed fractions branches (less than $2 \mathrm{~cm}$ ), flowers, seeds, fruits and leaves. Several studies conducted in Brazil refer only to the decomposition of leaf fraction and not the total litterfall, likely to decompose faster (VARJABEDIAN, 1988; YEONG et al., 2016; GOMES JÚNIOR et al., 2019).

\section{CONCLUSION}

The results suggest that the soil is lacking in nutrients, with high levels of exchangeable aluminum and extreme acidity, resulting in low fertility. These characteristics might influence the growth and phenology of trees and consequently the fall and decomposition of leaves. The litterfall showed a tendency of more production during raining seasons and a total value near of those found in tropical forest of the southeastern region of Brazil. The fall of tree material might be synchronized with the environment, but is not discharged the influence of São Paulo's atmospheric pollution in the litterfall dynamics, which should be deeply studied.

Through decomposition, the litterfall lost less material than expected for tropical forests. However, it is noteworthy that some environmental variables may have influenced the activity of decomposers and also some soil characteristics such as high acidity indirectly might have affected the proccess. Thus, the nutrient cycling resulting from the slow decomposition of litter fall does not contribute to an increase of nutrient stocks in the soil of this peri-urban forest, which highlight the attention to prioritize conservation purposes of the area.

\section{AKNOWLEDGEMENT}

We would like to thank the Forestry Institute of São Paulo for the field assistance.

\section{REFERENCES}


Alevs LF, Vierira SA, Scaranello MA, Camargo PC, Santos FAM, Joly CA, Martinelli, LA. Forest structure and live aboveground biomass variation along an elevational gradient of tropical Atlantic moist forest (Brazil). Forest Ecology and Management, Amsterdan, 2010; 679-691.

Aragão LEOC, Malhi Y, Metcalfe DB, Silva-Espejo, JE, Jimenez E, Navarrete D, Almeida, S, Costa ACL, Salinas N, Phillips OL, Anderson LO, Alvarez E, Baker TR, Gonçalvez PH, Huaman-Ovalle J, MamaniSolorzano M, Meir P, Monteagudo A, Patino S, Penuela MC, Prieto A, Quesada CA, Rozas-D'Ávila A, Rudas A, Silva JR, Vasquez R. Above-and belowground net primary productivity across ten Amazonian forests on contrasting soils, Biogeosciences, Göttingen. 2009; 6: 2759-2778.

ARATO, H.D.; MARTINS, S.V.; FERRARI, S.H.S. Produção e decomposição de serapilheira em um sistema agroflorestal implantado para recuperação de área degradada em Viçosa - MG. Revista Árvore, Viçosa, v. 27, p.715-721, 2003.

ARAÚJO, E.A.; KER, J.C.; MENDONÇA, E.S.; SILVA, I.R.; OLIVEIRA, E.K. Impacto da conservação florestapastagem nos estoques e na dinâmica do carbono e substâncias húmicas no solo do bioma amazônico. Acta Amazônica, Manaus, v. 41, p.103-114, 2011.

ARYAL, D.R.; DE JONG, B.H.J.; OCHOA-GAONA, S.; MENDOZA-VEGA, J.; ESPARZA-OLGIUM, L. Successional and seasonal variation in litterfall and associated nutriente transfer in semievergreen tropical forest of SE Mexico. Nutrient Cycling Agroecosystem, The Hague, v. 103, p.4560, 2015.

BATISTA, D.; PASCOAL, C.; CASSIO, F. Temperature modulates AgNP impacts on microbial decomposer activity. Science of The Total Environment, v. 601, p. 1324-1332, 2017.

BATJES, N.H. Total carbon and nitrogen in the soils of the world. European Journal of Soils Science, Oxford, v. 65, n.1, p.10-21, 2014.

BELLATO, S.M.; MENDES, I.A. Análise da suscetibilidade ambiental no Núcleo Curucutu do Parque Estadual da Serra do Mar (Sp - Brasil), In. GERARDI, L., MENDES, I.A. (Org). Do natural, do social e sua interações: visões geográficas: 93-108. Rio Claro, Ageteo, 2002.

CARDOSO, I.M.; KUYPER, T.W. Mycorrhizas and tropical soil fertility. Agriculture, Ecosystem and Environment, Amsterdan, v. 116, p.72-84, 2006.

CIANCIARUSO, M.V.; PIRES, J.S.R.; DELITTI, W.B.C.; SILVA, E.F.L.P. Produção e decomposição de material foliar em um cerradão na estação ecológica de Jataí, município de Luiz Antônio, SP, Brasil. Acta Botanica Brasilica, Porto Alegre, v. 20, n.1, p.49-59, 2006.

COSTA, O.V.; CANTARUTTI, R.B.; FONTES, L.E.F.; COSTA, L.M.; NACIF, P.G.S.; FARIA, J.C. Estoque de carbono do solo sob pastagem em área de tabuleiro costeiro no sul da Bahia. Revista Brasileira de Ciência do Solo, Viçosa, v. 33, n.5, p.1137-1145, 2009. 
ELLER, C.B.; LIMA, A.L.; OLIVEIRA, R.S. Foliar uptake of fog water and transport belowground alleviates drought effects in the cloud forest tree species, Drimys brasiliensis (Winteraceae). New Phytologist, London, v. 199, n.1, p.151-162, 2013.

EMBRAPA- Empresa Brasileira De Pesquisa Agropecuária. Sistema brasileiro de classificação de solos. $2^{\circ}$ ed. Brasília: Embrapa-SPI, 2006.

FERREIRA, M.L.; SILVA, J.L.; PEREIRA, E.E, LAMANO-FERREIRA, A.P.N. Litter fall production and decomposition in a fragment of secondary Atlantic Forest of São Paulo, SP, Southeastern, Brazil. Revista Árvore, Viçosa, v. 38, n.4, p.591-600, 2014a.

FERREIRA, M.L. PEREIRA, E.E.; MONTEURO, P. Ciclagem de nutrientes numa floresta urbana no município de São Paulo, SP. Periódico Técnico e Científico Cidades verdes, v. 2, n.2, p.1-17, 2014 b.

FERREIRA, M.L.; RIBEIRO, A.P.; ALBUQUERQUE, C.R.; FERREIRA, A.P.N.L.; FIGUEIRA, R.C.L.; LAFORTEZZA, R. Air contaminants and litter fall decomposition in urban forest areas: The case of São Paulo - SP, Brazil. Environmental Research, v. 155, p. 314-320, 2017.

FERREIRA, M.L.; UCHIYAMA, E.A. Litterfall assessement in a fragment of secondary tropical forest, Ibiúna, SP, southeastern Brazil. Revista Árvore, Viçosa, v. 39, p.791-799, 2015.

GOMES JÚNIOR, D., CALDEIRA, M. V. W., KLIPPEL, V. H., MENDONÇA, E. D. S., DELARMELINA, W. M., GODINHO, T. D. O., ROCHA, R. L. F. Decomposition of Leaf Litter in Semideciduous Submontane Forest, in The Southern State of Espírito Santo. Floresta e Ambiente, 26(SPE1): e20180400, 2019.

GRIMM, N.B.; FAETH, S.H.; GOLUBIEWSKI, N.E.; REDMAN, C.L.; WU, J.; BAI, X.; BRIGGS, J.M. Global change and the ecology of cities. Science, Washington, DC, v. 319, n.5864, p.756-760, 2008.

VAN GROENIGEN, J. W.; HUYGENS, D.; BOECKX, P.; KUYPER, TH. W.; LUBBERS, I. M.; RÜTTING, T.; GROFFMAN, P. M. The soil N cycle: new insights and key challenges. Soil, Gottingen, v. 1, p.235256, 2015.

HAMMER, $\varnothing$.; DAVID A. T. H.; RYAN, P. D. "PAST: paleontological statistics software package for education and data analysis." Palaeontologia electronica v. 4.n. 1, 2001.

HOOBIE, S.E.; VITOUSEK, P.M. Nutrient limitation of decomposition in Hawaiian forests. Ecology, Brooklyn, v. 81, n.7, p.1867-1877, 2000.

INSTITUTE EKOS BRASIL. Plano de manejo das unidades de conservação: Parque Estadual da Serra do Mar - Plano de Gestão. Brasil, 2006.

JESUS, P.R.; FILHO H.O.L.; FERREIRA, M.L. Litterfall production in three different sites with different abundance of eucalyptus (Eucalyptus spp.) at the Piqueri Park, SP. Brazilian Journal of Ecology, São Paulo, v. 01-02, p.59-65, 2014.

JOLY, C. A.; ASSIS, M. A.; BERNACCI, L. C.; TAMASHIRO, J. Y.; CAMPOS, M. C. R.; GOMES, J. A. M. A.; LACERDA, M. S.; SANTOS, F. A. M.; PEDRONI, F.; PEREIRA, L. S.; PADGURSCHI, M. C. G.; PRATA, E. M. B.; RAMOS, E.; TORRES, R. B.; ROCHELLE, A.; MARTINS, F. R.; ALVES, L. F.; VIEIRA, S. A.; 
MARTINELLI; L. A.; CAMARGO, P. B.; AIDAR, M. P. M.; EISENLOHR, P. V.; SIMÕES, E.; VILLANI, J. P.; BELINELLO, R. Floristic and phytosociology in permanent plots of the Atlantic Rainforest along an altitudinal gradient in southeastern Brazil. Biota Neotropica, (Ed. Portuguesa), Campinas, v. 12, n.1, p.123-145, 2012.

KRAEPIEL, A.M.L.; DERE, A.L.; HERDON, E.M.; BRANTLEY, S.L. Natural and anthropogenic process contributing to metal enrichment in surface soils of central Pensylvania. Biogeochemistry, Dordrecht, v. 123, p.265-283, 2015.

LIANG, B.; LEHMANN, J.; SOLOMON, D.; KINYANGI, J.; GROSSMAN, J.; O`NEILL, J.; SKJEMSTAD, J.O.; THIES, J.; LUIZÃO, F.J.; PETERSEN, J.; NEVES, E.G. Black carbon increases cation exchange capacity in soils. Soil Science Society of American Journal, Madison, v. 70, p.1719-1730, 2006.

LIRA, P.K.; TAMBOSI, L.R.; EWERS, R.M.; METZGER, J.P. Land-use and land-cover change in Atlantic Forest landscapes. Forest Ecology and Management, Amsterdan, v. 278, p.80-89, 2012.

MARIA, I.C.; ROSSETO, R. AMBROSANO, E.J.; CASTRO, O.M. Efeito da adição de diferentes fontes de cálcio no movimento de cátions em colunas de solo. Scientia Agrícola, Piracicaba, v. 50, p.87-98, 1993.

MARTINS, S.G; SILVA, M.L.N.; CURI, N.; FERREIRA, M.M. Avaliação de atributos físicos de um latossolo vermelho distroférrico sob diferentes povoamentos florestais. Cerne, Lavras, v. 8, n.1, p.32-41, 2005.

MARTINS, S.V. Ecologia de florestas tropicais do Brasil. 2a ed. Viçosa, MG: Editora UFV, 2012. 261 p.

MARTINS, S.C.; NETO, E.S.; PICCOLO, M.C.; ALMEIDA, D.Q.A.; CAMARGO, P.B.; CARMO, J.B.; PORDER, S.; LINS, S.R.M.; MARTINELLI, L.A. Soil texture and chemical characteristics along an elevation range in the coastal Atlantic Forest of Southeast Brazil. Geoderma Regional, Amsterdan, v. 5, p.106-116, 2015.

MENEZES, C. E. G.; PEREIRA, M. G.; CORREIA, M. E. F.; ANJOS, L. H. C.; PAULA, R. R.; SOUZA, M. E. Aporte e Decomposição da Serapilheira e Produção de Biomassa Radicular em Florestas com Diferentes Estágios Sucessionais em Pinheiral, RJ. Ciência Florestal, Santa Maria, v. 20, n.3, p.439452, 2010.

MCBRATNEY, A.B.; SANTOS, M.L.M.; MINASNY, B. On digital soil mapping. Geoderma, Amsterdan, v. 117, p.3-52, 2003.

McGRANAHAN, D.A. Landscape influence on recent rural migration in the U.S. Landscape and Urban Planning, Amsterdan, v. 85, n.3-4, p.228-240, 2008.

MYERS, N.; MITTERMEIER, R.A.; MITTERMEIER, C.G.; FONSECA, G.A.B.; KENT, J. Biodiversity hotspots for conservation priorities. Nature, London, v. 403, p.852-858, 2000.

NETO, J.M.T.M. Relações florísticas, estruturais e ecológicas entre as florestas do topo da Serra do Mar e as florestas de restinga no Estado de São Paulo, 2007. Tese de doutorado, departamento de Botânica, Instituto de Biociências da Universidade de São Paulo, 2007. 
OSTERTAG, R.; MARÍN-SPIOTTA, E.; SILVER, W.L.; SCHULTEN, J. Litterfall and decomposition in relation to soil carbon pools along a secondary forest chronosequence in Puerto Rico. Ecosystems, Nova lorque, v. 11, p.701-714, 2008.

PEREIRA, M.G.; MENEZES, L.F.T.; SCHULTZ, N. Aporte de decomposição de serapilheira na Floresta Atlântica, Ilha da Marambaia, Mangaratiba, RJ, Brasil. Ciência Florestal, Santa Maria, v. 18, n.4, p. 443-454, 2008.

PRESCOTT, C.E. Litter decomposition: what controls it and how can we alter it to sequester more carbon in forest soil? Biogeochemistry, Dordrecht, v. 101, p.133-149, 2010.

RAIJ, V.B.; CANTARELLA, H.; QUAGGIO,J.A.; ANDRADE, J.C. Análise Química para Avaliação da Fertilidade de Solos Tropicais. Campinas, SP: IAC, 2001, 285p.

RAIJ, B.V.; CANTARELLA, H.; QUAGGIO, J.A.; FURLANI, A.M.C. Recomendações de adubação e calagem para o Estado de São Paulo. Campinas, SP: IAC, Boletim Técnico, 100, 1985. p. 9-13.

RIBEIRO, M. C.; METZGeR, J. P.; MERTENSEN, A. C.; PONZONI, F. P.; HIROTA, M. M. The brazilian Atlantic forest, how much is left, and how much is the remanaing forest distributed? Implications for conservation. Biological Conservation, Barking, v. 142, p.1141-1153, 2009.

RODRIGUES, A.L.; WATZLAWICK, L.F.; GENÚ, A,M.; HESS, A.F.; EBLING, A.A.. Atributos de um solo florestal em uma topossequência e relações com a comunidade arbórea. Revista Floresta, Curitiba, v. 46, n. 2, p 145-154, 2016.

RONQUIM, C.C. Conceitos de fertilidade do solo e manejo adequado para regiões tropicais. Monitoramento Por Satélite, Campinas, SP: Embrapa, 2010.

ROWLAND L.; MALHI, T.; SILVA-ESPEJO, J. E.; FARFÁN-AMÉZQUITA, F.; HALLADAY, K.; DOUGHTY, C. E.; MEIR, P.; PHILLIPS, O. L. The sensitivity of wood production to seasonal and interannual variations in climate in a lowland Amazonian rainforest. Oecologia, Berlin, v. 174, p.295-306, 2014.

SALVADOR, J.O.; MOREIRA, A.; MALAVOLTA, E.; CABRAL, C.P. Influência do alumínio e na acumulação de nutrientes em mudas de goiabeira. Revista Brasileira de Ciência do Solo, Viçosa, v. 24, n.4, p.787-796, 2000.

SANCHEZ, P.A.; PALMA, C.A.; BUOL, S.W. Fertility capability soil classification: a tool to help assess soil quality in the tropics. Geoderma, Amsterdan, v. 114, p.157-185, 2003.

SCHEER, M.B. Decomposição e liberação de nutrientes da serapilheira foliar em um trecho de floresta ombrófila densa aluvial em regeneração, Guaraqueçaba (PR). Revista Floresta, Curitiba, v. 38, n. 2, p. 253-266, 2008.

SILVA, A.B. Fertilidade do solo, estoque serapilheira e sua decomposição após implantação de leguminosas arbustivo-arbóreas em pastagem. 2011. 73 p. Dissertação de mestrado, Departamento de Agronomia, Universidade Federal de Pernambuco, PE, 2011. 
SILVA, C.J.; SANCHES, L.; BLEICH, M. E.; LOBO, F.A. Produção de serrapilheira no Cerrado e Floresta de Transição Amazônia-Cerrado do Centro-Oeste Brasileiro. Acta Amazonica, Manaus, v. 37, n.4, p.543-548, 2007.

SOIL SURVEY STAFF. Soil taxonomy. A Basic System of Soil Classification for Making and Interpreting Soil Surveys, 1999.

SPECHT, M.J.; PINTO, S.R.R.; ALBUQUERQUE, U.P.; TABARELLI, M.; MELO, F.P.L. Burning biodiversity: Fuelwood harvesting causes forest degradation in human-dominated tropical landscapes. Global Ecology and Conservation, (s.1), v. 3, p.200-209, 2015.

TABARELLI, M. Tropical Biodiversity in Human-Modified Landscapes: What is our Trump Card? Biotropica, Washington, DC, v. 42, p.553-554, 2010.

THOMAS, G.A.; DALAL, R.C.; STANDLEY, J. No-till effects on organic matter, pH, cation exchange capacity and nutrient distribution in a Luvisol in the semi-arid subtropics. Soil \& Tillage Research, Amsterdan, v. 94, p.295-304, 2007.

TIAN, R; LI, H.; ZHU, H.; LIU, X.; GAO, X. $\mathrm{Ca}^{2+}$ and $\mathrm{Cu}^{2+}$ induced aggregation of variably charged soil particles: a comparative study. Soil Science Society of America Journal, Madison, v. 77, n. 3, p. 774-781, 2013.

UN. Population challenges and development goals. Viewed in http://www.un.org/esa/population/publications/pop_challenges/Population_Challenges.pdf. Access in 05 de october, 2015.

VARJABEDIAN, R.; PAGANO, S.N. Produção e decomposição de folhedo em um trecho de Mata Atlântica de encosta no município do Guarujá, SP. Acta Botanica Brasilica, Porto Alegre, v. 1, n.2, p.243-256, 1988.

VASCONCELLOS, R.L.F.; BINI, D.; PAULA, A.M.; ANDRADE, J.B.; CARDOSO, E.J.B.N. Nitrogênio, carbono e compactação do solo como fatores limitantes do processo de recuperação de matas ciliares.

Revista Brasileira de Ciências do Solo, Viçosa, v. 37, p.1164-1173, 2013.

VIEIRA, S. A.; ALVES, L. F.; AIDAR, M.; ARAUJO, L. S.; BAKER, T.; BATISTA, J. L. F.; CAMPOS, M. C.; CAMARGO, P. B.; CHAVE, J.; DELLITI, W. B. C.; HIGUCHI, N.; HONÓRIO, E.; JOLY, C. A.; KELLER, M.; MARTINELLI, L. A.; MATTOS, E. A.; METZKER, T.; PHILLIPS, O.; SANTOS, F. A. M.; SHIMABUKURO, M. T.; SILVEIRA, M.; TRUMBORE, S. E. Estimation of biomass and carbon stocks: the case of the Atlantic Forest. Biota Neotropica, (Ed. Portuguesa), Campinas, v. 8, n.2, 2008.

VITOUSEK, P.M. Litterfall, Nutrient Cycling, and Nutrient Limitation in Tropical Forests. Ecology, Brooklyn, v. 65, n.1, p.285-298, 1984.

YEONG, K. L.; REYNOLDS, G.; HILL, J. K. Leaf litter decomposition rates in degraded and fragmented tropical rain forests of Borneo. Biotropica, v. 48, n.4, 443-452, 2016.

WU, J.; ALBERT, L. P.; LOPES, A. P.; RESTREPO-COUPE, N.; HAYEK, M.; WIEDEMANN, K.T.; GUAN, K.; STARK, S.C.; CHRISTOFFERSEN, B.; PROHASKA, N.; TAVARES, J.V.; MAROSTICA, S.; KOBAYASHI, 
H.; FERREIRA, M.L. ; CAMPOS, K.S.; DA SILVA, R.; BRANDO, P.M.; DYE, D.G.; HUXMAN, T. E. ; HUETE, A.R.; NELSON, B.W. ; SALESKA, S.R. Leaf development and demography explain photosynthetic seasonality in Amazon evergreen forests. Science, Nova lorque, v. 351, p.972-976, 2016.

ZALAMEA, M., GONZÁLEZ, G. Leaffall Phenology in a Subtropical Wet Forest in Puerto Rico: From Species to Community Patterns. Biotropica, Washington, DC, v. 40, n.3, p.295-294, 2008. 